\title{
CLIMATE CHANGE IMPACT ON SALMON (SALMO SALAR) AND SEA TROUT (SALMO TRUTTA) IN THE SALACA RIVER, LATVIA
}

\author{
Janis Birzaks* \\ University of Daugavpils, Daugavpils, Latvia, Vienības street 13, LV-5401 \\ *Corresponding author. Email: janis.birzaks@du.lv
}

\author{
Article history \\ Received: 2 December 2019; \\ accepted 5 March 2020
}

\section{Keywords:}

Hydrometeorological trends; migration; smolt; par; temperature; streamflow

\begin{abstract}
Hydrometeorological conditions are important determinants of the distribution, abundance and growth of Atlantic salmon (Salmo salar) and sea trout (Salmo trutta) parr and smolt in rivers. Long-term monitoring of the temperate zone Salaca River was conducted to investigate long-term changes in water temperature and streamflow and their effects on juvenile Atlantic salmon and sea trout. The average water temperature in the Salaca River was found to increase over time, particularly in autumn, winter and spring. River discharge increased in winter and summer, which was caused by increased precipitation. Goals of our study were: 1 ) to examine trends in water temperature and discharge in the river, 2) to explore relations between hydrometeorological trends, on the one hand, and abundance, size at age of salmon and sea trout parr and smolt, as well as changes in smolt migration patterns, on the other. This was the first occasion that a study of this type had been carried out in the Baltic Sea basin. In summer, growth of salmon parr in all age groups in the Salaca River was reduced. However, the size of smolt was found to increase. Migration of sea trout smolt in the Salaca River took place earlier, and the end of both salmon and sea trout migration was also observed earlier. The age structure of salmon smolt changed, with the one-year- old age group dominating. Judging from the total numbers of salmon and sea trout smolt in the River Salaca, production of smolt in the river during the monitoring period increased.
\end{abstract}

\section{INTRODUCTION}

Hydrometeorological conditions, such as streamflow and water temperature, are among the most important environmental factors determining Atlantic salmon distribution and productivity in riverine habitats. Salmon is a stenothermic species, which requires well-oxygenated, clean and cool water and is sensitive to flow conditions (Elliot and Elliot 2010). These conditions affect the growth rate, development, behaviour and ultimate survival of young salmon. These variables control parr and smolt production, migration patterns and survival during downstream migration (Mather et al. 2008; Jonsson et al. 2016; Jonsson and Jonsson 2017).

Salmon can be encountered in 10 and sea trout in 15 river systems flowing through the Latvian territory. Besides, sea trout also occurs in one tenth of small rivers and brooks (HELCOM 2011). Salmon and sea trout spend from one to several years in East Baltic Rivers before they migrate to the sea as smolts in the early springsummer. Salmon and sea trout parr in the Salaca River and rivers in its basin are one to two summers old, while smolts are one to three years old (Mitans 1976).

The Salaca is a boreal zone river in the East Baltic, where salmon and sea trout smolt trapping has been conducted since 1964, and parr monitoring since 1992. Hydrometeorological monitoring is undertaken regularly in the river, and water temperature and river discharge are measured on a daily basis, providing an opportunity to examine long-term changes in temperature and streamflow and their effects on the abundance, growth, age structure and migration patterns of salmon and sea trout parr and smolts.

Salmon and sea trout populations in the Baltic Sea basin (HELCOM 2011; ICES 2018) are well documented, especially in the western and northern parts. East Baltic Rivers differ from these, especially in temperature, which in rivers of this region is higher and can exceed temperatures optimal for salmon (Elliot and Hurley 1997). This is also the case with the Salaca River.

This article analyses changes in long-term environmental factors (river discharge and water temperature), as well as changes in salmon and sea trout parr and smolt distribution, abundance, growth and behaviour in the river in the same period. Understanding these relationships is important for the management and conservation of wild salmon and sea trout populations in conditions of climate change.

\section{MATERIALS AND METHODS}

\section{Study area}

In northern Latvia, the Salaca River originates from the shallow lowland Lake Burtnieks and flows for about $95 \mathrm{~km}$ to its outlet in the Gulf of Riga (57 $45^{\prime} 21^{\prime \prime}$ $\left.24^{\circ} 20^{\prime} 00^{\prime \prime}\right)$ (Figure 1). 
Its annual average discharge is $31.3 \mathrm{~m}^{3} \mathrm{~s}^{-1}$, with a maximum of $184 \mathrm{~m}^{3} \mathrm{~s}^{-1}$ and a minimum of $4.4 \mathrm{~m}^{3} \mathrm{~s}^{-1}$. The Salaca River with its total basin area of $3,420 \mathrm{~km}^{2}$ (according to other data $-3,310 \mathrm{~km}^{2}$ in Latvian territory and $230 \mathrm{~km}^{2}$ in Estonian territory) ranks fifth in Latvia. Lake Burtnieks and the basins of its tributaries take up about $60 \%$ of the Salaca basin. The runoff of the Salaca River is also determined mainly by Lake Burtnieks, tributaries providing only $10-16 \%$ of the total runoff.

From mid-May to late September, water temperature in the Salaca stays above $+12^{\circ} \mathrm{C}$, reaching up to $+19-$ $+22{ }^{\circ} \mathrm{C}$ in July. In winter, the blanket of ice remains for an average of 80-90 days, however, frequent thaws, sludge and local ice movement can be observed.

In the late 19th century, a pulp mill was constructed on the Salaca at Staicele. A dam to meet the needs of the mill was constructed in 1896, and an hydro power station was set up in 1923. In 1986, the dam was partly demolished, but its foundations, in the form of a sloping ramp, were left in the river. They are surmountable for migratory fish such as sea trout and vimba when the water is high.

The size of the juvenile fish habitats available in the main Salaca River system, as estimated by habitat mapping, amounted to a total of 41 ha below the Staicele dam and 4 ha above the dam.

The Salaca River is connected with the Svêtupe River via the Jaunupe canal, which was dug in the 17 th century (Figure 1), and about $2 / 3$ of the river water flows into the Salaca. The majority of diadromous fish in the Jaunupe-Svettupe migrate through the Salaca. The area of juvenile fish habitats in the Jaunupe and Svētupe rivers were estimated at about 5 ha. The area of sea trout and salmon habitat in the other small rivers and streams in the Salaca River basin is not known.

There was a state owned hatchery operating in the Salaca since the 1970 s, but its operation was terminated in 2000. Currently, the Salaca and its basin territory in Latvia is included in a Biosphere Sanctuary, and the Salaca valley has Natura 2000 territory status. The Salaca River is one of the Index Rivers for wild salmon monitoring in Europe (ICES 2018).

Cyprinid fish species, roach Rutilus rutilus, chub Squalius cephalus, gudgeon Gobio gobio as well as pike Esox lucius and perch Perca fluviatilis dominate the ichthyofauna of the Salaca. Pikeperch Stizostedion luciperca has been introduced into the river basin, and an alien species, crucian carp Carassius gibelio, can be encountered. In the salmon parr habitat area, the dominating species are stone loach Barbatula barbatula, salmon, bullhead Cottus gobio and minnow Phoxinus phoxinus. Trout, stone loach and minnow are the most frequently encountered species in the tributaries.

\section{Salmon and sea trout monitoring in the Salaca River}

The long-term data on salmon and sea trout were gathered within the framework of various state research

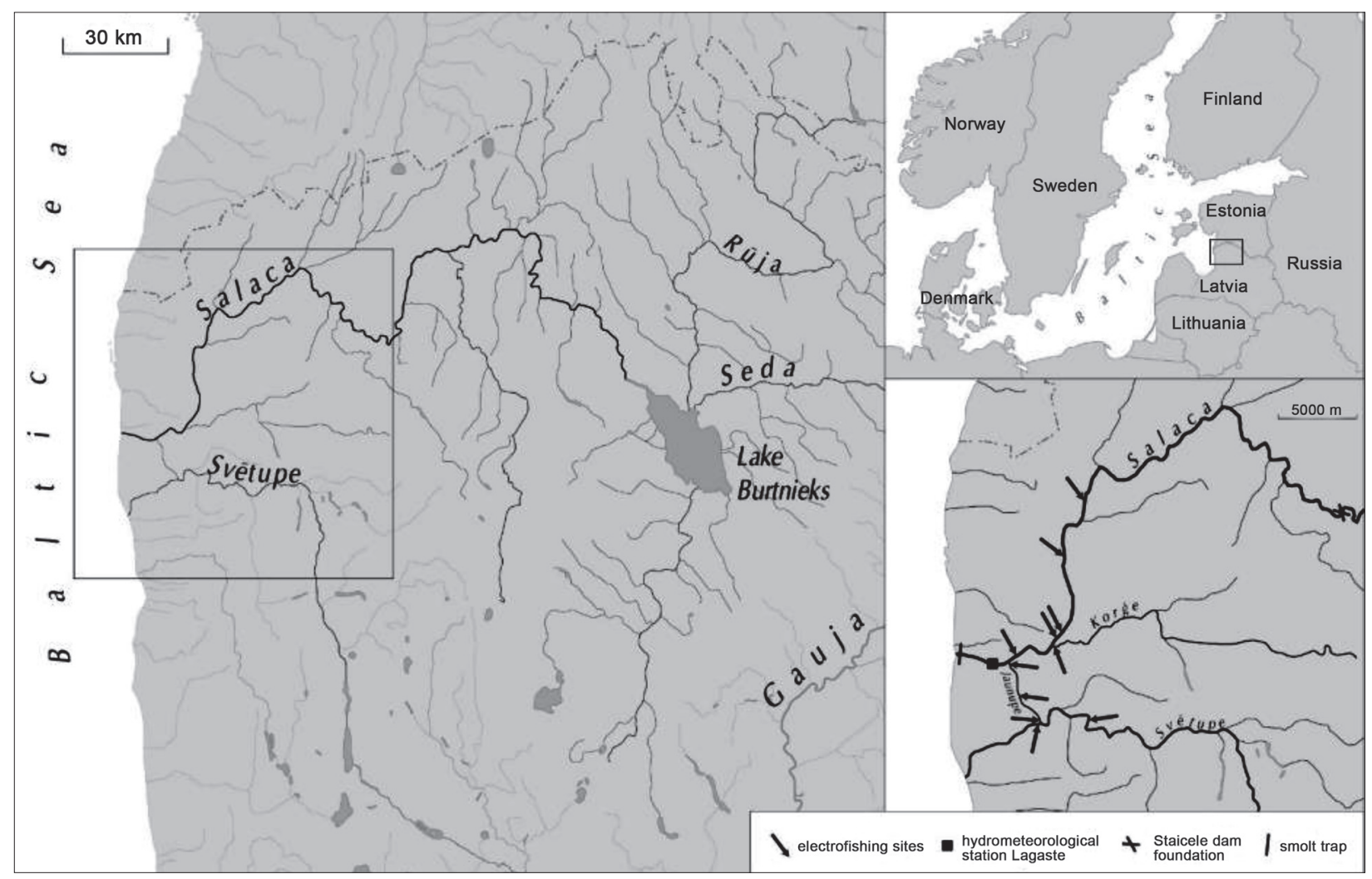

Figure 1. Location of sampling sites in the Salaca River basin. 
programmes implemented by several institutions in Latvia: the Baltic Sea Fisheries Research Institute (BaltNIIRH), the Latvian Fisheries Research Institute (LZPI), the Latvian Fish Resources Agency (LZRA) and the Food Safety, Animal Health and Environment Institute (BIOR).

All monitoring procedures were carried out under appropriate national licences and regulations.

The smolt run in the Salaca River has been evaluated since 1964 by catching the downstream migrants in a fyke-net type smolt trap. The trap is placed in the lower reaches of the river, at a distance of $0.4 \mathrm{~km}$ from the river outlet. The trap net consists of two side arms and a smolts collecting box with the mesh size $18 \mathrm{~mm}$ (from knot to knot) in side arms and $12 \mathrm{~mm}$ in the smolt box. The trap is placed in the central flow of the river, occupying about $20 \%$ of its width (the width of the river at this site is $120 \mathrm{~m}$ ).

The smolt trap in the Salaca River was in operation from the end of April to the end of May or early June, between the 118th and the 167th days of the year on average.

The trap was checked daily in the early morning to record the number of smolts captured, to identify their species and to measure the fork-length of smolts. Trapping efficiency was evaluated through mark-recapture experiments, which were undertaken 5-10 times per season. Until 2004, smolts were marked by cutting off a corner of the caudal fin. The smolts that were captured later and those that are caught at present were and are, respectively, tagged with external streamer tags (Floy Tag). All marked fish specimens were transported $2 \mathrm{~km}$ upstream and released. Tags from recaptured fish as well as the date and time of recapture were recorded. A single mark - recapture effort yielded no fewer than 50 specimens of marked smolts.

The fork length of all smolts was measured to the nearest millimetre and scale samples from 200 individuals were taken 2-3 times during migration season.

The beginning of migration was identified with the date of the first smolt capture in a trap net, and the end, with the capture of the last one. The pace of migration was defined as the number of days from the beginning of the year, when $25 \%, 50 \%$ and $75 \%$ of the total smolt run (cumulative catch) migrated.

Salmon and sea trout parr have been monitored since 1992 by electrofishing at 10 permanent sites in the Salaca River and its tributaries the Jaunupe-Svētupe and the Korge (Figure 1). The average size of sampling sites was $350 \mathrm{~m}^{2}$. Electrofishing was carried out in the first week of August every year. To increase the number of the salmon specimens observed, sites for monitoring were selected from the best habitats, rather than randomly assigned or selected from a stratified sample.
A 3-pass electrofishing/removal method (Bohlin et al. 1989) was preferred, each electrofishing effort lasting 20-40 minutes. DC current of $10 \mathrm{~A}$ at $300 \mathrm{~V}$ was used in electrofishing, the current being supplied by a $2 \mathrm{~kW}$ generator.

The fork length of all salmon and sea trout parr was measured to the nearest millimetre.

\section{Hydrometeorological data}

The Latvian Environment, Geology and Meteorology Centre collected the average daily water temperature $\left({ }^{\circ} \mathrm{C}\right)$ and discharge $\left(\mathrm{m}^{3} \mathrm{~s}^{-1}\right)$ data for the Salaca River.

The water temperature was measured every 15 minutes. The flow of the Salaca River was measured 7 times per year, while daily flow data for the rest of the time were obtained from the discharge data estimated from the water level.

The seasons were defined as follows: winter (DecemberMarch), spring (April-May), summer (June-August) and autumn (September-November).

The time series encompassed 1964-2017 at Lagaste meteorological station (Figure 1).

\section{Data processing}

Smolt trap efficiencies and population estimates were calculated using a standard, single mark-recapture session (Petersen estimator) (Moran 1951; Seber 1982; Carlson et al. 1998). The overall run estimates, obtained from emigration trapping operations, are totals of the daily run estimates, based on the average trap efficiency and calculated as the sum of daily trap catches.

Smolt trap efficiency, estimated from the fin-clipped smolt in the period 1964-2003 and streamer tags' recapture rate in the period 2004-2017, varied from $5.9-12.7 \%$ with an average of $9.7 \%$ of the tagged fish released upstream.

The age of smolts was determined by scale analysis of random samples according to the methods proposed by Pravdin (1966).

The population of fish at the electrofishing site was estimated from three successive removals using the maximum likelihood procedure (Zippin 1956; Seber 1982). Separate population estimates were generated for $0+$ and older salmon parr for each site. Density was expressed as the number of fish per $100 \mathrm{~m}^{2}$ of the habitat area.

Annual lengths and lengths at ages were calculated from databases, which encompass 45,947 salmon and 13,450 sea trout smolt specimens, with age determined by scale reading. All parr specimens smaller than $100 \mathrm{~mm}$ were classified as $0+$ parr, but $>100 \mathrm{~mm}$ specimens as $1+$ and older parr. 
A single linear regression was used to measure the strength of any relationship between the salmon and sea trout parr and smolt numbers, relative abundance, length at age and smolt migration patterns and hydrometeorological parameters such as water temperature and discharge with a significance level $\alpha=0.05$.

The non-parametric Mann-Kendall (Hirsch et al. 1982; Hirsch and Slack 1984) test for monotonic trends in the time series of data grouped by years and months was chosen to identify significant trends in environmental variables, smolt migration patterns and changes in age composition, size at age and abundance of young salmon and sea trout in the same period. The test was applied separately to each variable at a significance level of at least $p<0.05$. A trend was considered to be statistically significant at the $5 \%$ level if the test statistic $Z$ was $>2$ or $<-2$. To show the direction of the trend, the signs + (increasing trend) or - (decreasing trend) were used. The trend in length for smolt is $n=54$ years and parr $n=26$ years.

\section{RESULTS}

\section{Environmental data}

In the period 1964-2017, the average water temperature in the Salaca River was $8.5^{\circ} \mathrm{C}$ with extremes of $7.29^{\circ} \mathrm{C}$ to $9.46^{\circ} \mathrm{C}$. During the period of smolt migration in April, May and June, it was $4.98^{\circ} \mathrm{C}(\min =2.27-$ $\max =8.83), 13.07{ }^{\circ} \mathrm{C}(\min =10.2-\max =17.1)$ and $18.05^{\circ} \mathrm{C}(\min =14.7-\max =22.2)$, respectively. The highest water temperatures in the Salaca are observable from June to August, when they reach or sometimes exceed $22{ }^{\circ} \mathrm{C}$, while the highest temperature $26.9{ }^{\circ} \mathrm{C}$ was recorded in 2010.

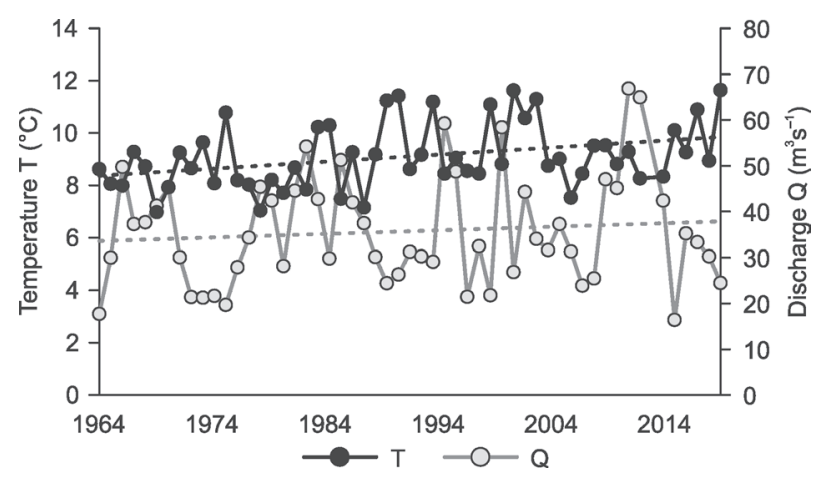

Figure 2. Trends in average water temperature $(\mathrm{T})$ and discharge $(\mathrm{Q})$ in the Salaca River.

Analysis of the temperature trend shows that it increased during autumn and winter months and in early spring from November until April and September but decreased in June (Table 1). The number of days with extremely high water temperatures $\left(>22^{\circ} \mathrm{C}\right)$ in June and August, the warmer months of the year $\left(Z=+1.79, R^{2}=0.006\right.$, $p=0.07)$, did not increase, and neither did the average water temperature in summer at this time. On average, for $175(\min =134-\max =205)$ days of the year, the water temperature in the Salaca River was between 6 and $22{ }^{\circ} \mathrm{C}$, and this trend in number of days did not change significantly $\left(\mathrm{z}=+1.73, \mathrm{R}^{2}=0.06, p=0.08\right)$.

Extremely high water temperatures (above $22^{\circ} \mathrm{C}$ ) in the Salaca River were exceeded in 16 out of 54 summers. No significant changes in the trend of extreme high water temperatures were observed in the river.

Hydrometeorological observations were not undertaken in tributaries of the Salaca River. Their water temperature, measured during parr electrofishing, was lower by $2-2.5{ }^{\circ} \mathrm{C}$ than that in the Salaca River and rarely reached $20^{\circ} \mathrm{C}$.

The average discharge in the Salaca River in the 1964-2017 period was $20.2 \mathrm{~m}^{3} \mathrm{~s}^{-1}$, with extremes of $9.8-36.9 \mathrm{~m}^{3} \mathrm{~s}^{-1}$. The greatest discharge in the Salaca River is recorded in December-May, when it exceeds the average annual value and is between 24 and $42 \mathrm{~m}^{3} \mathrm{~s}^{-1}$. Earlier snowmelt/runoff causes an earlier start of a drier summer-autumn season, when the river discharge is 9-16 $\mathrm{m}^{3} \mathrm{~s}^{-1}$. Like temperature, discharge increases in winter months, i.e. from December to March, as well as in summer, i.e. from June to August, with an increase in precipitation. During the 1964-2017 period, the average Salaca River discharge increased (Table 1, Figure 2).

In the winter period, as well as in spring, during the period of salmon and sea trout smoltification and migration, water temperature in the Salaca River changed becoming less harsh. An increase in water temperature was also recorded in autumn, in the pre-spawning and spawning period of salmon and sea trout. The river discharge increased in winter and summer. In fact, one or two of the environmental parameters, which were analysed for changes in one of the seasons, changed increasing significantly (Table 1).

\section{Salmon and sea trout parr abundance, age and size}

Salmon reproduction in the Salaca River basin mainly takes place in the Salaca River, and to a smaller degree in its tributaries, the Jaunupe-Svētupe and Korğe Rivers. In the period 1992-2017, the average abundance of one-summer-old salmon parr was 59.8 ind. $\left(100 \mathrm{~m}^{2}\right)^{-1}$ $(\min =11.1, \max =137.6)$ and that of one-year-old fish $4.9(\min =0.8, \max =17.9)$. These indicators in tributaries of the Salaca River were 10.9 and 0.4 ind. $\left(100 \mathrm{~m}^{2}\right)^{-1}$ respectively (Table 2 , Figure 1$)$.

Sea trout reproduction mainly takes place in tributaries of the Salaca River. Abundance of sea trout parr in the main river was on average only 2.0 ind. $\left(100 \mathrm{~m}^{2}\right)^{-1}$, $(\min =0, \max =9.2)$, while in tributaries it was 28.3 ind. $\left(100 \mathrm{~m}^{2}\right)^{-1}(\min =5.1, \max =74.7($ Table 2, Figure 3$)$. 
Table 1. Trends in average water temperature and discharge changes by months in the Salaca River (1964-2017).

\begin{tabular}{|c|c|c|c|c|c|c|}
\hline & \multicolumn{3}{|c|}{ Water $\mathrm{t}\left({ }^{\circ} \mathrm{C}\right)$} & \multicolumn{3}{|c|}{ Discharge $\left(\mathrm{m}^{3} / \mathrm{s}\right)$} \\
\hline & $\mathrm{Z}$ & $\mathrm{R}^{2}$ & $p$ & $\mathrm{Z}$ & $\mathrm{R}^{2}$ & $p$ \\
\hline January & +5.63 & 0.44 & $<0.001$ & +3.43 & 0.17 & $<0.001$ \\
\hline February & +4.32 & 0.34 & $<0.001$ & +3.69 & 0.11 & $<0.001$ \\
\hline March & +2.90 & 0.12 & 0.011 & +2.67 & 0.08 & 0.008 \\
\hline April & +3.62 & 0.24 & $<0.001$ & ns & & \\
\hline May & ns & & & ns & & \\
\hline June & -2.76 & 0.13 & 0.004 & +2.40 & 0.11 & 0.002 \\
\hline July & ns & & & +2.95 & 0.10 & 0.003 \\
\hline August & ns & & & ns & & \\
\hline September & 2.1 & 0.08 & 0.004 & ns & & \\
\hline October & ns & & & ns & & \\
\hline November & +3.06 & 0.17 & 0.002 & ns & & \\
\hline December & +5.03 & 0.35 & $<0.001$ & ns & & \\
\hline Annual 1964-2017 & +3.94 & 0.25 & $<0.002$ & +2.96 & 0.11 & 0.03 \\
\hline Winter & +5.42 & 0.53 & $<0.001$ & +3.83 & 0.19 & $<0.001$ \\
\hline Spring & +2.57 & 0.12 & 0.010 & ns & & \\
\hline Summer & ns & & & +2.51 & 0.07 & 0.012 \\
\hline Autumn & +3.13 & 0.15 & 0.002 & ns & & \\
\hline
\end{tabular}

Note: ns - non-significant.

Table 2. Salmon and sea trout parr age structure, average length $(\mathrm{mm})$ and density $\left(\mathrm{n}\left(100 \mathrm{~m}^{2}\right)^{-1}\right)$.

\begin{tabular}{|c|c|c|c|c|}
\hline & \multicolumn{2}{|c|}{ Salmon } & \multicolumn{2}{|c|}{ Sea trout } \\
\hline & $0+$ & older & $0+$ & older \\
\hline \multicolumn{5}{|l|}{ Age (\%) } \\
\hline Salaca & 92.4 & 7.6 & 90.0 & 10.0 \\
\hline Tributaries $^{1}$ & 96.5 & 3.5 & 86.9 & 13.1 \\
\hline \multicolumn{5}{|c|}{ Average length } \\
\hline Salaca & $67.0 \pm 6.6$ & $115.0 \pm 6.3$ & $65.0 \pm 8.7$ & $147.6 \pm 38.4$ \\
\hline Tributaries $^{1}$ & $77.6 \pm 6.4$ & $123.4 \pm 16.8$ & $67.8 \pm 4.5$ & $142.8 \pm 9.0$ \\
\hline \multicolumn{5}{|c|}{ Average density } \\
\hline Salaca & $59.8 \pm 31.1$ & $4.9 \pm 3.9$ & $1.8 \pm 1.9$ & $0.2 \pm 0.4$ \\
\hline Tributaries $^{1}$ & $10.9 \pm 14.8$ & $0.4 \pm 0.7$ & $24.6 \pm 16.0$ & $3.7 \pm 2.5$ \\
\hline
\end{tabular}

Note: ${ }^{1}$ - Jaunupe-Svētupe, Korǵe.

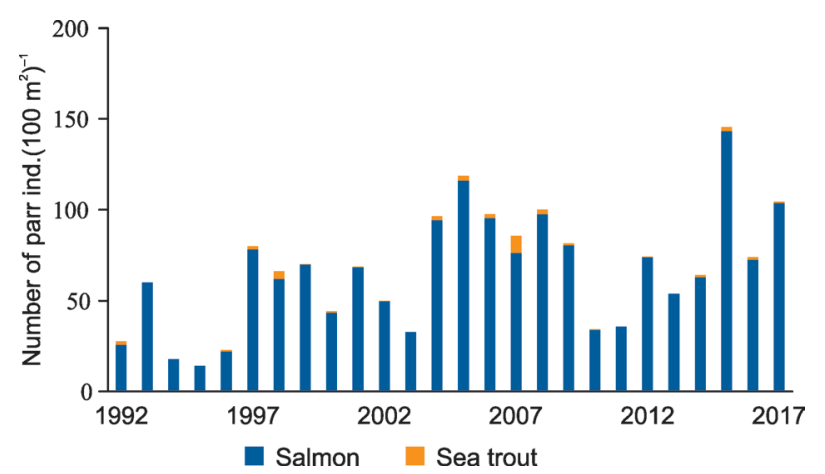

Figure 3. Salmon and sea trout parr abundance ind. $\left(100 \mathrm{~m}^{2}\right)^{-1}$ in the Salaca River.

The observations in the Salaca River above the former Staicele Dam, which until now had been conducted only irregularly, revealed that sea trout reproduction also takes place in the upper reaches of the Salaca River and in tributaries in this stretch of the river. This fact evinces that sea trout are able to get over foundations of the Staicele dam. In this stretch of the river, salmon parr were not recorded.

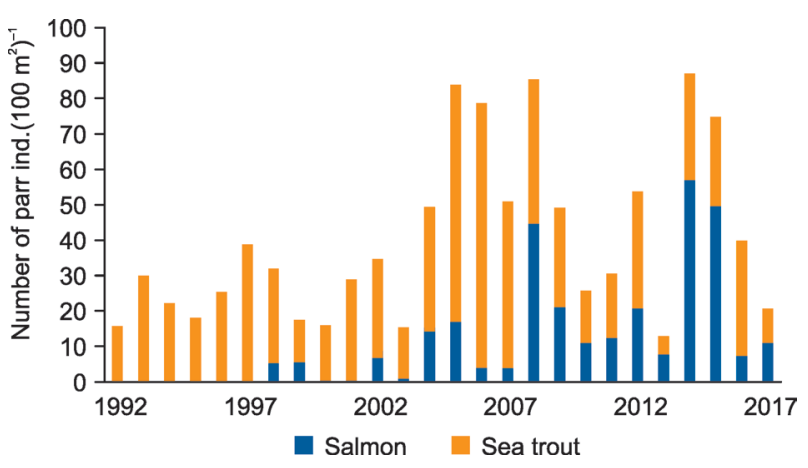

Figure 4. Salmon and sea trout parr abundance ind. $\left(100 \mathrm{~m}^{2}\right)^{-1}$ in tributaries of the Salaca River.

Long-term data show that in the period of our surveys regular salmon reproduction in tributaries of the river has been taking place only since 1998 (Figure 4). In the period 1992-2017, salmon 0+parr abundance in the Salaca as well as in its tributaries increased. The Mann-Kendall statistics were significant, at $\mathrm{z}=+2.49$, $\mathrm{R}^{2}=0.16, p=0.01$ (Table 3). In the summer season, when water temperature was rising, the number of 
0+ parr both in the Salaca River and in its tributaries $\left(\mathrm{F}(1.23)=5.82, p=0.05\right.$ with an $\left.\mathrm{R}^{2}=0.27\right)$ decreased.

Salmon parr in the Salaca River and its tributaries belong to two age groups, one- summer-old $(0+)$ and one-yearold $(1+)$ fish. The abundance of parr in both age groups grew in the Salaca and in its tributaries (Table 3).

One- summer-old $(0+)$ parr accounted for more than $90 \%$ (Table 2) and older parr for 3-13\% of the total number. The average length of one-summer old salmon parr was $67.0 \pm 6.6 \mathrm{~mm}$, and that of one-year old parr $115.0 \pm 6.3 \mathrm{~mm}$. In the Salaca River, the average length of salmon parr in both age groups decreased with $\mathrm{z}=-3.17, \mathrm{R}^{2}=0.42, p=0.002$ and $\mathrm{z}=-2.07, \mathrm{R}^{2}=0.16$, $p=0.04$ respectively (Figure 5).

In the younger group of parr, length was found to decrease with increasing parr abundance $F(1.23)=6.22$, $p<0.01$. Such a correlation was not observed in sea trout parr. The average length of sea trout parr in the

Table 3. Trends in salmon and sea trout parr abundance in the Salaca River and its tributaries (1992-2017).

\begin{tabular}{|l|c|c|c|c|c|c|}
\hline \multirow{2}{*}{$\begin{array}{c}\text { Parr age } \\
\text { group }\end{array}$} & \multicolumn{3}{|c|}{ Salmon } & \multicolumn{3}{c|}{ Sea trout } \\
\cline { 2 - 7 } & $\mathrm{Z}$ & $\mathrm{R}^{2}$ & $p$ & $\mathrm{Z}$ & $\mathrm{R}^{2}$ & $p$ \\
\hline Salaca & & & & & & \\
\hline $0+$ & +2.49 & 0.16 & 0.01 & $\mathrm{nd}$ & & \\
\hline older & +2.03 & 0.12 & 0.04 & $\mathrm{nd}$ & & \\
\hline Tributaries & & & & & & \\
\hline $0+$ & +4.28 & 0.36 & $<0.001$ & $\mathrm{~ns}$ & & \\
\hline older & +3.64 & 0.27 & $<0.001$ & $\mathrm{~ns}$ & & \\
\hline
\end{tabular}

Note: ns - non-significant, nd - not determined due to the small number of parr.

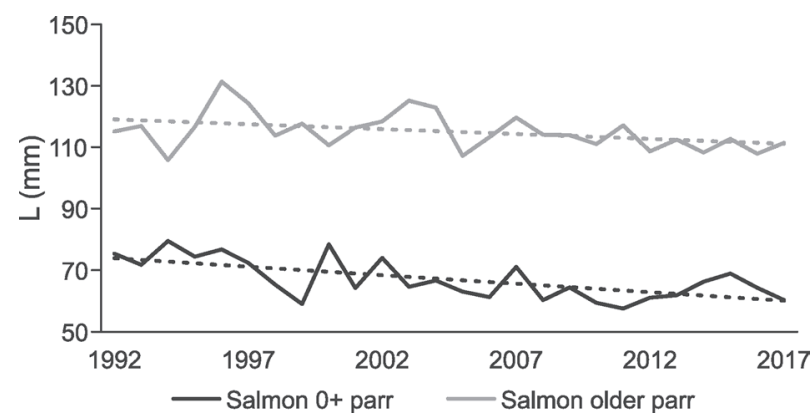

Figure 5. Salmon parr length $(\mathrm{mm})$ in the Salaca River.

Table 4. Trends in salmon and sea trout parr lengths in the Salaca River and its tributaries (1992-2017).

\begin{tabular}{|l|c|c|c|c|c|c|}
\hline \multirow{2}{*}{} & \multicolumn{3}{|c|}{ Salmon } & \multicolumn{3}{c|}{ Sea trout } \\
\cline { 2 - 7 } & $\mathrm{Z}$ & $\mathrm{R}^{2}$ & $p$ & $\mathrm{Z}$ & $\mathrm{R}^{2}$ & $p$ \\
\hline Salaca & & & & & & \\
\hline $0+$ & -3.17 & 0.22 & 0.002 & $\mathrm{nd}$ & & \\
\hline older & -2.07 & 0.16 & 0.04 & $\mathrm{nd}$ & & \\
\hline Tributaries & & & & & & \\
\hline $0+$ & $\mathrm{ns}$ & & & $\mathrm{ns}$ & & \\
\hline older & $\mathrm{nd}$ & & & +2.53 & 0.24 & 0.01 \\
\hline
\end{tabular}

Note: ns - non-significant, nd - not determined due to the small number of parr. younger age group was $67.8 \pm 4.5 \mathrm{~mm}$, and that in the older age group $-142.8 \pm 9.0 \mathrm{~mm}$.

In both age groups, the average length of salmon parr showed a significant negative trend, and their average length in the period since 1992 decreased with increasing abundance (Table 4).

In summer, with increasing water temperature $\left.\left(\mathrm{F}(1.23)=5.73, p<0.05, \mathrm{R}^{2}=0.22\right)\right)$ and discharge $\left(\mathrm{F}(1.23)=8.77, p<0.01, \mathrm{R}^{2}=0.29\right)$, salmon growth slowed.

\section{Smolt migration, number, age structure and size}

In the period 1964-2017, salmon and sea trout smolt production in the Salaca River ranged between 2.9 and 52.6 thousand. During the study period, the number of salmon smolts did not change significantly, but production of sea trout smolts increased significantly $\left(\mathrm{z}=+5.73, \mathrm{R}^{2}=0.46, p<0.001\right)$. In certain years, sea trout production was close to salmon production, but since 2009-2011, production of sea trout smolts has been exceeding that of salmon smolts (Figure 6).

Migration of salmon and sea trout smolt took place between the last week of April and the first week of June. In general, the first specimens of sea trout smolt got trapped when the river water temperature reached $5^{\circ} \mathrm{C}$, and the first specimens of salmon smolt were captured when water in the river warmed up to $8^{\circ} \mathrm{C}$. It was found that smolt migration takes place when water discharge Q drops from 70 to $20 \mathrm{~m}^{3} \mathrm{~s}^{-1}$ and water temperature T increases to $16-17^{\circ} \mathrm{C}$ (Figure 7).

Salmon smolt migration usually takes place between the 107 th and the 190th day of the year and is on average 40 days long, while that of sea trout smolt lasts from the 101 st to the 169th day of the year, its length averaging 36 days. Sea trout smolt migration takes place earlier and is shorter than that of salmon smolt.

The following changes were observed in salmon and sea trout smolt migration during the study period: salmon migration lasted for a shorter period of time and finished quicker, while migration of sea trout smolt began and finished earlier (Table 5).

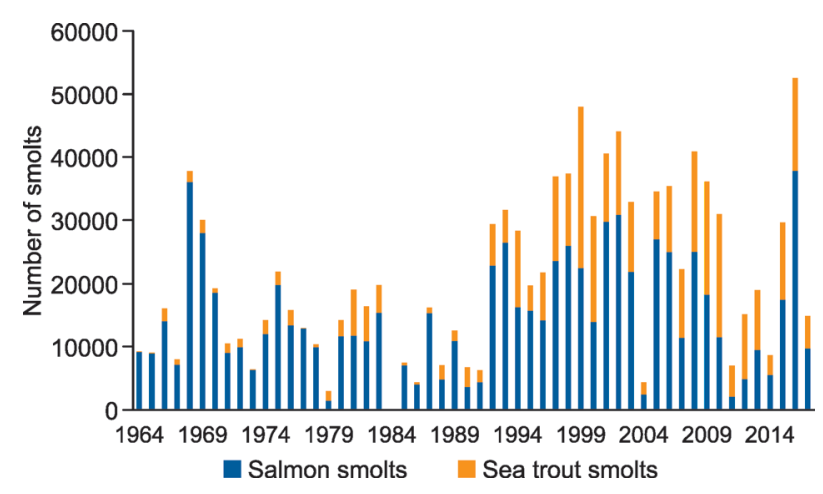

Figure 6. Salmon and sea trout smolt production in the Salaca River. 


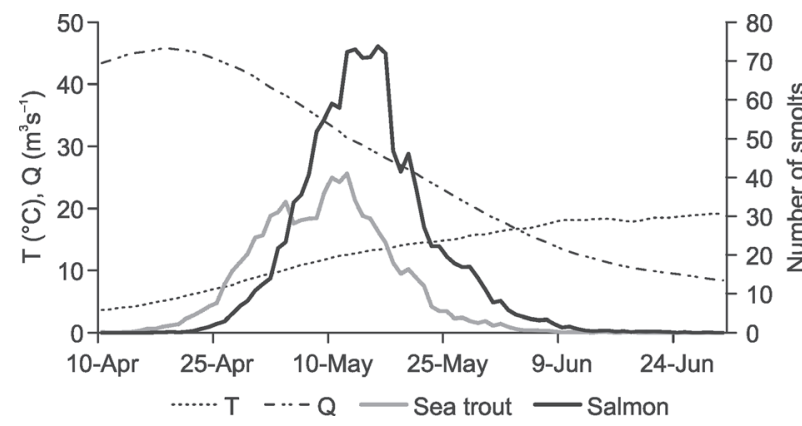

Figure 7. Patterns of salmon and sea trout smolt (counted in trap) migration in the Salaca River. $\mathrm{T}=$ water temperature; $\mathrm{Q}=$ water discharge.

Table 5. Trends in salmon and sea trout smolt migration (1964-2017).

\begin{tabular}{|l|c|c|c|c|c|c|}
\hline & \multicolumn{3}{|c|}{ Salmon } & \multicolumn{3}{|c|}{ Sea trout } \\
\cline { 2 - 7 } & $\mathrm{Z}$ & $\mathrm{R}^{2}$ & $p$ & $\mathrm{Z}$ & $\mathrm{R}^{2}$ & $p$ \\
\hline $\begin{array}{l}\text { Beginning of } \\
\text { smolt run }\end{array}$ & $\mathrm{ns}$ & & & -4.63 & 0.40 & $<0.001$ \\
\hline $\begin{array}{l}25 \% \text { of smolt } \\
\text { run }\end{array}$ & $\mathrm{ns}$ & & & -3.02 & 0.19 & $p=0.003$ \\
\hline $\begin{array}{l}50 \% \text { of smolt } \\
\text { run }\end{array}$ & $\mathrm{ns}$ & & & -2.40 & 0.15 & $p=0.016$ \\
\hline $\begin{array}{l}75 \% \text { of smolt } \\
\text { run }\end{array}$ & $\mathrm{ns}$ & & & -2.52 & 0.14 & $p=0.012$ \\
\hline $\begin{array}{l}\text { End of smolt } \\
\text { run }\end{array}$ & -4.03 & 0.27 & $<0.001$ & -2.90 & 0.09 & 0.004 \\
\hline Smolt run days & -2.88 & 0.18 & 0.040 & $\mathrm{~ns}$ & & \\
\hline
\end{tabular}

Note: ns - non-significant.

Salmon and sea trout smolts were classified into the following three age-groups: 1-, 2- and 3-year-old fish (Table 6). The analysis of trends in the age composition of salmon smolt shows that the proportion of $1+$ age fish significantly increased $\left(\mathrm{z}=+2.15, \mathrm{R}^{2}=0.16, p=0.032\right)$, but the number of individuals in the oldest smolt group decreased $\left(\mathrm{z}=-2.02, \mathrm{R}^{2}=0.10, p=0.044\right)$ (Figure 8$)$. The number of three-year-old salmon smolts in the overall salmon smolt production in the Salaca River was found to be relatively insignificant. The age structure of sea trout smolt did not change significantly during the study period. The size of sea trout smolts by age groups was larger than that of salmon smolts and the number of three-year-old fish was also greater (Table 6).

The smolt size of both species at age, excluding twosummer-old sea trout smolts, increased, which is confirmed by significant positive trends in the MannKendall statistic (Table 7). This type of relationship was not observed for sea trout smolts.

In the period 2004-2017, the number of salmon smolts, as estimated by streamer tags, highly increased $\mathrm{F}(1.13)=72.49), p<0.001$ with the number of $0+$ salmon parr increasing a year before smolting (Figure 9).
Table 6. Average fork length and age structure of salmon and sea trout smolts (1964-2017).

\begin{tabular}{|c|c|c|c|c|}
\hline $\begin{array}{c}\text { Age group } \\
\text { (years) }\end{array}$ & \multicolumn{2}{|c|}{ Salmon } & \multicolumn{2}{c|}{ Sea trout } \\
$\mathrm{L}_{\mathrm{s}} \pm \mathrm{SD}(\mathrm{mm})$ & $\mathrm{N} \%$ & $\mathrm{~L}_{\mathrm{s}} \pm \mathrm{SD}(\mathrm{mm})$ & $\mathrm{N} \%$ \\
1 & $110.6 \pm 7.8$ & 45.9 & $116.8 \pm 13.4$ & 42.6 \\
\hline 2 & $134.4 \pm 10.2$ & 52.6 & $144.1 \pm 23.1$ & 44.7 \\
\hline 3 & $160.8 \pm 9.4$ & 1.5 & $192.9 \pm 25.6$ & 12.7 \\
\hline
\end{tabular}

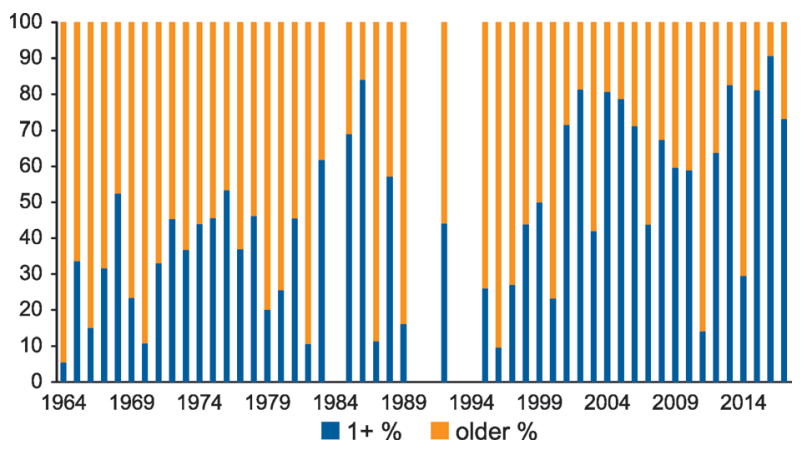

Figure 8. Salmon smolt age composition (percentage) in the Salaca River.

Table 7. Trends in smolt size by age in the Salaca River (1964-2017)

\begin{tabular}{|c|c|c|c|c|c|c|}
\hline \multirow{2}{*}{$\begin{array}{c}\text { Age, } \\
\text { years }\end{array}$} & \multicolumn{3}{|c|}{ Salmon } & \multicolumn{3}{c|}{ Sea trout } \\
\cline { 2 - 7 } & $\mathrm{Z}$ & $\mathrm{R}^{2}$ & $p$ & $\mathrm{Z}$ & $\mathrm{R}^{2}$ & $p$ \\
\hline 1 & +3.66 & 0.27 & $<0.001$ & +2.63 & 0.38 & 0.009 \\
\hline 2 & +3.12 & 0.30 & 0.002 & +2.04 & 0.21 & 0.040 \\
\hline 3 & +3.08 & 0.32 & 0.002 & ns & & \\
\hline
\end{tabular}

Note: ns - non-significant.

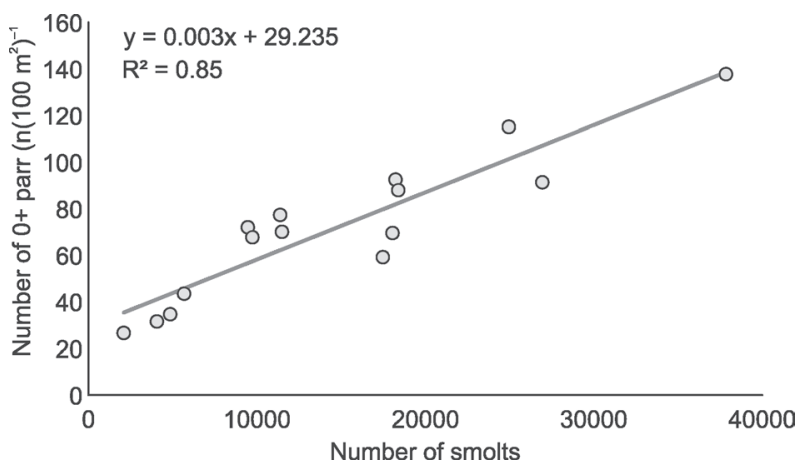

Figure 9. Number of salmon smolts and $0+$ parr density a year before smolting in the Salaca River.

\section{DISCUSSION}

Temperature and discharge of water in rivers are determined by the regional climate (Harrod et al. 2009). The mean annual air temperature in the Baltic Sea region has been increasing by $0.11 \mathrm{C}$ per decade over the past 140 years. Because of this change, the cold season is becoming shorter and the amount of precipitation in the form of rain is increasing during the winter period and in spring. River discharge is decreasing in the southern part 
of the Baltic Sea basin, but in the north it is increasing (HELCOM 2013).

In Latvia, climate change is relatively well documented. Hydrometeorological data analysis shows that statistically significant changes in river discharge can be observed in the winter season, which corresponds with less severe winters in the region (Lizuma et al. 2007). In winter (December-February), discharge shows a significantly increasing trend, while no trend has been identified in other seasons. A decreasing linear trend indicates a reduction in ice cover duration and a shift towards earlier ice break-up dates (Klavins et al. 2009). Climate extremes show that the number of very hot days is increasing, and that of cold spells, in contrast, is decreasing (Avotniece et al. 2012). Water temperature in regional rivers correlates with the air temperature, and, because of the climate change in the Baltic Sea area, has a tendency to increase in other Baltic Sea basin rivers as well (Ptak et al. 2016). An increase in the annual air temperature in the Salaca River basin, milder winters with higher water temperature and an increase in river discharge were observed (Klavins et al. 2009). The Salaca River is characterised by substantial snowmelt floods and comparatively small rainfloods in autumn, with 50-60\% of total run-off taking place in spring (Klavins et al. 2002). A reduction in oxygen content in river water was also detected in the summer period (Springige et al. 2011).

It was against this background of the above-mentioned changes that an increasing abundance of salmon parr and increasing water temperature in winter was recorded in the Salaca River basin. Higher temperature days during the winter period cause faster individual development and earlier emergence of parr from the gravel substrate of spawning nests and a longer growing season as a result (Jonsson and Jonsson 2009). Salmon eggs, incubated at a higher temperature, produced larger and better surviving parr than those incubated at a lower temperature (Skoglund et al. 2011). Likewise, mild winters obviously imply a higher survival rate of salmon fry, as parr abundance, especially that of one-summer- old individuals, is increasing in the Salaca River.

Also, the high abundance of salmon parr leads to intraspecific competition-induced growth rate reduction, which was evidenced by a shortening of the average fork length measured in both groups of salmon parr during salmon monitoring in August.

Our research shows that regular salmon reproduction in tributaries of the Salaca River has been taking place since 1998 with a resultant increase in the area of salmon distribution in the river basin. This may have been predetermined by the partial displacement of salmon spawners to smaller rivers, where the water temperature in summer is lower by $1-2{ }^{\circ} \mathrm{C}$ than that in the Salaca River.
The life cycles of salmon and sea trout parr in rivers finishes as they smoltify and migrate to the sea. Smolt migration takes place during spring and early summer. Individuals that immigrate from fresh water to the sea maintain a high growth rate in late summer and early autumn a year before smolting, compared to that of non-emigrating fish, which smoltify a year later as two year old smolts (Mitans 1972; Thorpe et al. 1998). Fast growing parr tend to smoltify earlier, at smaller size than the slower growing older individuals from the same population. Data on the Welsh River Dee for a 60-year period showed a shift in smolt age and an increase in parr growth: currently, smolts in the Dee River migrate at a larger size and at a younger age (Aprahamian et al. 2008).

Our results show that warmer winters and earlier springs ensure survival and smoltification of a greater proportion of parr. There is an increase in the proportion of the fastest-developing parr that undergo smoltification at a younger age as one-year-old smolts in the Salaca River. As a result of improved conditions for parr growth in autumn until the beginning of winter and in spring until the beginning of migration, the average size of one-yearold salmon and sea trout smolt in the river increased. The average length of older smolt also increased.

The timing of migration has an important role in smolt survival in the marine environment (McCormick et al. 1998). Smoltification takes place in fresh water, in a limited period of readiness (smolt "window"), during which the ability to adapt to life in the sea and the ensuing seaward migration develops (McCormick and Saunders 1987). Research results show that smolts may use environmental triggers in the rivers that predict favourable sea conditions to initiate downstream migration (McCormick et al. 1998; Hvidsten et al. 2009).

It was found that different populations appear to be ready to enter the sea when the sea temperature reaches $8{ }^{\circ} \mathrm{C}$ (Hvidsten et al. 2009). This implies that smolts from southern populations migrate earlier than smolts from northern populations, where the sea temperature reaches the preferable levels later in the season. It is hypothesized that the timing of the sea run is associated with the selection of optimal conditions in the sea. This is confirmed by the research results indicating that post - smolt survival is higher at sea water temperatures $8-10{ }^{\circ} \mathrm{C}$, than at temperatures $5-7^{\circ} \mathrm{C}$ (Friedland et al. 1998). These findings are in agreement with the research data on salmon reported from the Simojoki River (northern Gulf of Bothnia), where the optimal temperature range for smolt migration was reported to be $9-12{ }^{\circ} \mathrm{C}$, with lower survival in colder or warmer years (Jutila et al. 2005). Overall, smolt migration takes place in a three- to seven-week period, with more early timing in southern populations. In rivers in the northern part of the Baltic Sea, smolt migration begins in June, in the Gulf 
of Finland it begins in May and in the main part of the Baltic in April-May (Mitans 1967, Jutila et al. 2003; Kesminas and Virbickas 2003; Skrupskelis et al. 2012; Kesler et al. 2013). We found climate change-induced changes in smolt migration patterns in the Salaca River. Smolt migration period has become shorter, i.e., it proceeds more intensively, its rate correlating negatively with the water temperature during migration.

The overall production of smolt in the Salaca River increased due to the increased abundance of sea trout smolt, which could have been caused by climate change. Flow conditions (higher runoff in the summer) in small headwater streams in the Salaca River basin, where sea trout reproduction takes place, allow sea trout spawners to migrate upstream. The Salaca River has more than 20 unmonitored first level tributaries suited to sea trout. Sea trout reproduction was found to increase in the Salaca River, particularly in its upper course tributaries (personal communication with the State Environmental Service Inspectorate).

In summary, over the last 50 years, such environmental conditions as water temperature and discharge in the Salaca River have changed, directly or indirectly affecting the abundance, distribution, growth and migration patterns of young salmon and sea trout. Overall, the results show that the age of smolts has decreased, but length at age increased, which can be viewed either as a response to climate warming, or an improvement in their feeding conditions, or both.

This situation is likely to continue into the future in accordance with climate change scenarios and will influence salmon and sea trout resources accordingly. Monitoring and research to gain a better understanding of the impact that environmental conditions exert on the dynamics of fish populations in the region is of great importance for management of salmonid resources.

\section{REFERENCES}

Aprahamian, M. W., I. C. Davidson, and R. J. Cove. 2008. Life history changes in Atlantic salmon from the River Dee, Wales. Hydrobiologia 602: 61-78.

Avotniece, Z., M. Klavins, and V. Rodinov. 2012. Changes of Extreme Climate Events in Latvia. Environmental and Climate Technologies 9: 4-11.

Bohlin, T., S. Hamrin, T. G. Heggeberget, G. Rassmusen, and S. J. Saltveit. 1989. Electrofishing - Theory and practice with special emphasis on salmonids. Hydrobiologia 173: 9-43.

Carlson, S. R., L. G. Jr. Coggins, and C. Swanton. 1998. A simple stratified design for mark-recapture estimation of salmon smolt abundance. Alaska Fishery Research Bulletin 5: 88-102.
Elliott, J. M., and J. A. Elliott. 2010.Temperature requirements of Atlantic salmon Salmo salar, brown trout Salmo trutta and Arctic charr Salvelinus alpinus: predicting the effects of climate change. Journal of Fish Biology 77: 1793-1817.

Elliott, J. M., and M. A. Hurley. 1997. A functional model for maximum growth of Atlantic salmon parr, Salmo salar, from two populations in northwest England. Functional Ecology 11: 592-603.

Friedland, K. D., L. P. Hansen, and D. A. Dunkley. 1998. Marine temperatures experienced by postsmolts and the survival of Atlantic salmon, Salmo salar L., in the North Sea area. Fisheries Oceanography 7: 22-34.

Harrod, C., C. Graham, and J. Mallela. 2009. Climate change and the fishes of Britain and Ireland. Journal of Fish Biology 74: 1143-1205.

HELCOM. 2011. Salmon and Sea Trout Populations and Rivers in the Baltic Sea - HELCOM assessment of salmon (Salmo salar) and sea trout (Salmo trutta) populations and habitats in rivers flowing to the Baltic Sea. Baltic Sea Environment Proceedings: 126A.

HELCOM. 2013. Climate change in the Baltic Sea Area: HELCOM thematic assessment in 2013. Baltic Sea Environment Proceedings: 137.

Hirsch, R. M., and J. R. Slack. 1984. A nonparametric trend test for seasonal data with serial dependence. Water Resources Research 20 (6): 727-732.

Hirsch, R. M., J. R. Slack, and R. A. Smith. 1982. Techniques of trendanalysis for monthly water quality data. Water Resources Research 18 (1):107-121.

Hvidsten, N. A., A. J. Jensen, A. H. Rikardsen, B. Finstad, J. Aure, S. Stefansson, P. Fiske, and B. O. Johnsen. 2009. Influence of sea temperature and initial marine feeding on survival of Atlantic salmon Salmo salar post-smolts from the Rivers Orkla and Hals, Norway. Journal of Fish Biology 74: 1532-1548.

ICES. 2018. Report of the Baltic Salmon and Trout Assessment Working Group (WGBAST), 20-28 March 2018, Turku, Finland. ICES CM 2018/ACOM: 10: 369.

Jonsson, B., and N. Jonsson. 2009. A review of the likely effects of climate change on anadromous Atlantic salmon Salmo salar and brown trout Salmo trutta, with particular reference to water temperature and flow. Journal of Fish Biology 75: 2381-2447.

Jonsson, B., and N. Jonsson. 2017. Fecundity and water flow influence the dynamics of Atlantic salmon. Ecology of Freshwater Fish 26 (3): 497-502.

Jonsson, B., N. Jonsson, and J. Albretsen. 2016. Environmental change influences the life history of salmon Salmo salar in the North Atlantic Ocean. Journal of Fish Biology 88: 618-637.

Jutila, E., E. Jokikokko, and M. Julkunen 2003. Anagement of Atlantic salmon in the Simojoki River, northern Gulf of Bothnia. Fisheries Research 64: 5-17.

Jutila, E., E. Jokikokko, and M. Julkunen. 2005. The smolt 
run and postsmolt survival of Atlantic salmon, Salmo salar L., in relation to early summer water temperatures in the northern Baltic Sea. Ecology of Freshwater Fish 14: 69-78.

Kesler, M., M. Vetemaa, L. Saks, and T. Saat. 2013. Survival of reared Atlantic salmon (Salmo salar) smolts during downstream migration and its timing: a case study in Pirita River. Boreal environment research 18: 53-60.

Kesminas, V., and T. Virbickas. 2003. Baltic salmon (Salmo salar L.) in Lithuania: distribution, abundance and state. In Atlantic salmon: biology, conservation and restoration, edited by A. Je. Veselov, E. P. Ieshko, N. N. Nemova, O. P. Sterligova, Yu. A. Shustov. Petrozavodsk: 45-51.

Klavins, M., A. Briede, V. Rodinov, I. Kokorite, and T. Frisk. 2002. Long-term changes of the river runoff in Latvia. Boreal Environment Research 7: 447-456.

Klavins, M., A. Briede, and V. Rodinov. 2009. Long term changes in ice and discharge regime of rivers in the Baltic region in relation to climatic variability. Climate Change 95: 485-498.

Lizuma, L., M. Klavins, A. Briede, and V. Rodinovs. 2007. Long-term changes of air temperature in Latvia. In Climate change in Latvia, edited by M. Klavins, 11-21. Riga: UL Publishing House.

Mather, M. E., D. L. Parrish, C. A. Campbell, J. R. McMenemy, and J. M. Smith. 2008. Summer temperature variation and implications for juvenile Atlantic salmon. Hydrobiologia 603, 183-196.

McCormick, S. D., and R. L. Saunders. 1987. Preparatory physiological adaptations for marine life of salmonids: osmoregulation, growth and metabolism. American Fisheries Society Symposium 1: 211-229.

McCormick, S. D., L. P. Hansen, T. P. Quinn, and R. L. Saunders. 1998. Movement, migration, and smolting of Atlantic salmon (Salmo salar). Canadian Journal of Fisheries and Aquatic Sciences 55 (Suppl. 1): 77-92.

Mitans, A. R. 1967. The River Salaca Salmon smoltification, migration patterns and smolt abundance. In Fisheries research in the Baltic sea 2: 35-51. Riga (In Russian).
Mitans, A. R. 1972. Importance of freshwater life to dynamics of Baltic salmon abundance. Prpceedings of VNIRO 33: 269-284 (In Russian).

Mitans, A. R. 1976. On the dynamics of the population of salmon in the Baltic Sea. Salmonidae fish, morphology, systematics and ecology. Leningrad: 79 p. (In Russian).

Moran, P. A. P. 1951. A mathematical theory of animal trapping. Biometrika 38: 3-4, 307-311.

Pravdin, I. F. 1966. A guide to fish study. Food Industry. Moscow (In Russian).

Ptak, M., A. Choiński, and J. Kirviel. 2016. Long-term water temperature fluctuations in coastal rivers (southern Baltic) in Poland. Bulletin of Geography. Physical Geography Series 11: 35-42.

Seber, G. A. F. 1982. The Estimation of Animal Abundance and Related Parameters. 2nd edition. London: Edward Arnold.

Skoglund, H., S. Einum, and G. Robertsen. 2011. Competitive interactions shape offspring performance in relation to seasonal timing of emergence in Atlantic salmon. Journal of Animal Ecology 80: 365-374.

Skrupskelis, K., S. Stakenas, T. Virbickas, and N. Nika. 2012. Age and size of migrating Atlantic salmon, Salmo salar L., and sea trout, Salmo trutta L., smolts in Lithuanian rivers. Arch. Pol. Fish. 20: 255-266.

Springge, G., J. Birzaks, A. Briede, I. Druvietis, L. Grīnberga, I. Konošonoka, E. Parele, V. Rodinov, and A. Skuja. 2011. Climate Change Indicators for Large Temperate River: Case Study of the River Salaca. In Climate Change in Latvia and Adaptation to it, edited by M. Kl̦aviņš and A. Briede, 79-94. Rīga: University of Latvia Press.

Thorpe, J. E., M. Mangel, N. B. Metcalfe, and F. A. Huntingford. 1998. Modelling the proximate basis of salmonid life-history variation, with application to Atlantic salmon, Salmo salar L. Evolutionary Ecology 12: 581-599.

Zippin, C. 1956. An evaluation of the removal method of estimating animal populations. Biometrics 12: 163-189. 